\title{
Social Networks and Religion: The Role of Congregational Social Embeddedness in Religious Belief and Practice
}

\author{
Samuel Stroope* \\ Department of Sociology, Baylor University
}

\begin{abstract}
Previous literature argues that social networks influence religiosity, but surprisingly, no studies have used national data of a variety of religious traditions to assess the relationship between embeddedness in congregation-based friendship networks and different dimensions of religiosity. This study uses new national data (Baylor Religion Survey 2007) to estimate models of religious activity (church activities and devotional activities) and of religious belief (supernatural beliefs, biblical literalism, and religious exclusivity). Among U.S. Christians, congregational social embeddedness is a robust predictor of all religiosity outcomes and is among the largest effects in models. These effects are not substantially moderated by religious tradition, although Catholic affiliation attenuates the positive relationship between social embeddedness and church activities. These findings strongly suggest that social sanctions and solidarity rewards within congregational social networks play an important role in heightening religiosity. Religious research would be enhanced by devoting greater attention to the importance of congregational social embeddedness.
\end{abstract}

Key words: social network; social embeddedness; social ties; social encapsulation; friends; social sanctions; congregational support; religion.

To what degree do social networks forged in religious congregations shape religiosity? The idea of social immersion in a community of worshippers has been central in classical sociological work examining religious phenomena (Durkheim [1912] 1995). Researchers have linked the religious composition of social networks to outcomes as varied as life satisfaction (Lim and Putnam 2010), coital onset (Adamczyk 2009), controlled substance use (Burkett and Warren 1987), and religious conversion (Lofland and Stark 1965). In general, as a person's social ties are consolidated in a group, the group exacts pressure on the individual more intensely, conforming both action and belief to the

*Direct correspondence to Samuel Stroope, Department of Sociology, Baylor University, One Bear Place \#97326, Waco, TX 76798-7326, USA. E-mail: sam_stroope@baylor.edu.

(C) The Author 2011. Published by Oxford University Press on behalf of the Association for the Sociology of Religion. All rights reserved. For permissions, please e-mail: journals.permissions@oup.com. 


\section{SOCIOLOGY OF RELIGION}

network. Additionally, social immersion in the group draws individuals toward alignment with the group's practices and ideology through the high levels of emotional rewards gained in the course of social interaction. Networks within religious groups may be particularly important because social relations and roles in the group become infused with a moral force or solidarity that takes on otherworldly significance (Berger 1967:38).

A long line of literature reviews the connection between religious phenomena and social bonds in religious congregations but measurement has often been indirect. For example, the proportion of friends in an individual's denomination, a common measure, is imprecise, producing inconsistent results; a stronger measure is possible "if the relationship ties are within the same congregation or parish" Cornwall (1989: 574). In line with this argument, the present study focuses on the proportion of an individual's friends drawn from his or her religious congregation, "social embeddedness." Much of the earlier research exploring the relationship between social embeddedness and religiosity used regional or denominational samples of limited generalizability, and excluded controls now standard. The present study builds on prior work by including important controls, using more precise measures from a new national survey of multiple religious traditions, and by using a wider array of religious activity and belief outcomes. To be sure, the link between social networks and religiosity is a vast topic. Rather than tackle its broad multidimensionality here, it is important to stress that my more limited goal is to examine congregational social embeddedness' connection with several religious activity and belief outcomes.

This study fills a gap in the sociology of religion and social networks literature by assessing whether social embeddedness in religious congregations is associated with religious activity and religious belief while holding constant key background characteristics of individuals and their congregations. I use Wave 2 of the Baylor Religion Survey, one of the few national datasets permitting analysis of relationships between congregational social embeddedness and numerous measures of religiosity $(N=1,648)$. I test for robust embeddednessreligiosity associations, the strength of associations, and whether the associations are moderated by the religious tradition of congregations. Acquiring a clearer understanding of the relationship between congregational social embeddedness and religiosity has implications for the persistence of religious belief and practice and for associated consequences for individuals and communities.

\section{THEORETICAL AND EMPIRICAL BACKGROUND}

Social networks are important in numerous areas of life including health, civil society, and economic sociology (Granovetter 1973; Marsden and Friedkin 1993; McAdam 1986; Moody and Paxton 2009). The solidarity found in social networks has also long been central in the sociology of religion (Lofland and Stark 1965), and recent research points to the significance of 
in-group ties within religious congregations in particular (Scheitle and Finke 2008). This embeddedness-religion connection is consistent with the idea that social encapsulation in a voluntary association can affect the individual through monitoring, social sanctions, and social rewards. Social embeddedness can facilitate monitoring of an individual because the person frequently sees and is seen by the network members and is reminded that positive or negative sanctions arise as a result of her commitment to the group's activities and values (Hechter 1988; Marsden and Friedkin 1993). For example, a seeming lack of commitment to the group's beliefs may result in gossip about the individual and could lead to a marred reputation and status loss (Burt and Knez 1995). Similarly, Coleman (1990) argues that the higher the social network closure, the more likely it is that network monitoring and sanctioning will develop and be effective. Also, the more an individual's social ties are consolidated in a particular group, the more intensely the group can place pressure on the person (Blau and Schwartz 1984), conforming actions and beliefs to those of the group network (Granovetter 1992). Positive social sanctions may also be powerful in heightening a person's religiosity through "solidarity rewards" (Collins 1997).

Research on friendships and religion supports the idea of social embeddedness' influence, indicating that a greater proportion of friendships drawn from an individual's congregation is central to stronger religious commitment (Cavendish et al. 1998; Cornwall 1989; Hammond 1992; McIntosh et al. 2002; Welch 1981). But sociologists also know that religion is a multifaceted area of social life (Stark and Glock 1968), consisting of distinct domains such as religious practice and belief. Scholars often differentiate between external religiosity (e.g., church volunteering) and internal religiosity (e.g., beliefs and cognitions), both as outcomes (Barrett et al. 2007) and as independent variables with distinct effects (cf., Bader and Desmond 2006; Nonnemaker et al. 2006). But the question remains: to what degree are religious activities, and religious beliefs tied to social embeddedness in religious congregations?

\section{Social Embeddedness and Religious Activities}

A considerable literature shows connections between the religious composition of friendship networks and religious activities (Barrett et al. 2007; Erickson 1992; Kadushin and Kotler-Berkowitz 2006; Martin et al. 2003; Mears and Ellison 2000; Regnerus et al. 2004). Unfortunately, these studies are mainly limited to adolescents and are also limited in that they do not consider the consolidation of friendships in the respondent's congregation, but rather measure the religious composition of general friendship networks. Some research has considered social embeddedness among friendships in a congregation, and results are consistent with an embeddedness-religious behavior connection. For instance, McIntosh et al. (2002) find social embeddedness in a congregation to be positively associated with church participation in a sample of older adults. Similarly, Cavendish et al. (1998) find social embeddedness in 


\section{SOCIOLOGY OF RELIGION}

Catholic parishes to be the strongest predictor of religious activities including sharing faith, Bible study group involvement, and Mass attendance.

Ellison and Sherkat (1995) also examine the connections between social embeddedness and religious activities. They find that among southern, rural African Americans, outward religiosity is high even when religious salience is low, suggesting social network pressure to conform to outward participation in a "semi-involuntary institution." As a broader theoretical backdrop to these findings, Ellison (1995) argues that individual religious choices are too often theorized outside the context of social relations. He proposes a relational approach to religious behavior: where social ties are consolidated in local religious institutions, people must visibly participate in religious institutions in order to remain in good standing with their social relations and secure ongoing emotional, religious, and nonreligious benefits. In this sense, social networks use both rewarding and punitive sanctions as individuals' outward religious conformity varies. Norms become internalized through past and anticipated reactions of the surrounding relations. In short, Ellison (1995:91) suggests that external participation is pulled along by desired reactions from social relations including approval or being regarded as an exemplary person in the eyes of others. These mechanisms can be summarized under the ideas of monitoring and sanctioning (including positive sanctions) by an individual's surrounding relationships, promoting commitment and behavior conforming to the organization in which the relationships are nested. Taken together, the above literature leads to the following expectation:

Hypothesis 1

The more an individual's friendships come from his or her congregation, the more an individual will participate in religious activities.

\section{Embeddedness and Religious Belief}

Social network scholars commonly assume that social embeddedness influences people's beliefs (Emirbayer and Goodwin 1994:1424-36; Wellman and Berkowitz 1988) and the sociology of religion literature generally maintains that social embeddedness affects religious belief (Berger 1967; Roberts and Davidson 1984; White 1968). The argument that participation in a religious community precedes religious belief dates back at least to Durkheim's Elementary Forms of Religious Life. In the religious recruitment literature, dense social relations play a significant role in recruitment and retention processes of new religious movements, sects, and churches (Abel 2006; Kalir 2009; see Kane and Park 2009:367 for a recent review; Lofland and Stark 1965; Olson 1989; Smilde 2005; Snow et al. 1980; Stark 1995; Stark and Bainbridge 1980). This literature draws a causal arrow from social ties to beliefs, and group solidarity is understood to play a significant role (Collins 1997; Stark and Bainbridge 1985:307-24). 
Along similar lines, Berger's (1967) notion of plausibility structures, tightly knit worlds of social relations that uphold beliefs, is a well-known theory of social embeddedness and religious belief. Berger reasons that for a worldview to remain plausible, individuals must be enmeshed in a network of fellow believers that can socially support the beliefs. Put simply, "the subjective reality of the world hangs on the thin thread of conversation" (Berger 1967:17; see also Smith et al. 1998:106-7). Although it seems almost taken for granted that social networks directly influence religious beliefs, empirical studies along these lines are surprisingly few and are limited in a number of important ways. For example, one of the few studies that predicts religious beliefs utilizing congregational social embeddedness is Welch's (1981) study that uses a geographically and denominationally restricted sample of Northern California Protestants. Welch finds that the proportion of church-based friendships is positively associated with the certainty of Christian beliefs and belief in religious exclusivity. But we do not know whether these associations are present in the broader American religious landscape. The above background leads to the following hypothesis:

Hypothesis 2

The more an individual's friendships come from his or her congregation, the more an individual will adhere to religious beliefs.

\section{Religious Traditions and Social Embeddedness}

In addition to the estimated net effects of social embeddedness, the effects of embeddedness may be contingent upon the theological climate of the congregation in which persons are embedded (Stroope 2011c). For example, in predicting traditional religious beliefs, embeddedness in a theologically liberal congregation may come with weaker social sanctions than embeddedness in a theologically conservative congregation. A similar pattern may also apply to religious activities. Differing theological orientations of congregations attach greater or lesser importance to the activities that take place within the congregation. These theological orientations also communicate positive or negative evaluations of nonchurch activities in which individuals may participate. For instance, evangelical Protestants generally maintain an orientation that focuses on the primacy of the church's activities, often teaching that church-based activities such as evangelism are of eternal significance (Emerson and Smith 2000; Hunter 1981; Polson 2008). Activities not tied to evangelistic goals, such as volunteering for a secular charity, are generally taught to be of only earthly significance and of questionable value since God would not receive glory for the work of a secular charity. Furthermore, worldly activities pose a threat in that they might draw the believer away from church involvement. Not surprisingly, evangelical congregations encourage relatively few secular activities for members (Ammerman 2005). Evangelical congregations also expect stronger commitment and participation from congregants and so the 


\section{SOCIOLOGY OF RELIGION}

social networks of such congregations should more clearly negatively sanction worldly activities and more consistently provide positive social sanctions for church-based activities (Iannaccone 1994; Stark and Bainbridge 1985). While it is true that Black Protestant congregations have maintained a strong focus on social issues beyond the bounds of the church, these congregations also maintain a theological orientation that places strong otherworldly value on church-based activities (Ellison and Sherkat 1995; Putnam and Campbell 2010:260-319).

\section{Hypothesis 3}

The effects of social embeddedness on religious activities and beliefs will be stronger for evangelical Protestants and Black Protestants as compared to mainline Protestants or Catholics.

\section{DATA AND METHODS}

The data for this study are from the 2007 administration of the BRS. The BRS was designed using the General Social Survey (GSS) as a model, and demographically, the BRS compares well to the GSS and other national surveys (Bader et al. 2007). Although the BRS contains questions on numerous topics ranging from civic engagement to political tolerance, the bulk of the set content of the BRS consists of religion items. The BRS (a random, national sample of 1,648 U.S. citizens), was administered and collected by the Gallup Organization. Using mixed-mode national random sampling design, phone interview plus mailed questionnaires and mailed questionnaires only were used, resulting in a response rate of 47.1 percent of total individuals contacted and 67 percent for the mailed survey. Although less than ideal, the BRS response rate is well within the parameters of recent national surveys and are certainly appropriate for the purposes of this study because the precision of parameter estimates using sample data are minimally related to response rates (see American Association for Public Opinion Research 2008; Singer 2006).

The BRS provides a new opportunity for examining social embeddedness' connection to various forms of religious activity and belief. In addition to questions about participation in religious educational programs, outreach, prayer, and scripture reading, respondents were asked about involvement in church activities in the last month including volunteering, social gatherings, and religious choir participation. Numerous questions about belief are also included, such as certainty of the existence of spiritual beings, places, and the eligibility of different religious groups for heaven. The BRS also includes a measure of how many of the respondent's friends attend their particular congregation, what will be referred to as social embeddedness. This social embeddedness measure is important because it taps an individual's level of encapsulation within a local, particular, and relatively stable religious social world-the 
proportion of friendships drawn from the individual's congregation. This is a more precise measure of network embeddedness than questions about the general religious or denominational affiliation of friends in unspecified religious groups and while certainly not a perfect congregational embeddedness measure, it provides a new opportunity to test previously theorized relationships and examine whether prior empirical results hold in a multidenomination national sample. To my knowledge, this specific measure of social embeddedness is not found in combination with this array of religious belief and activity items in other datasets. ${ }^{1}$

The analysis begins with descriptive statistics of all study measures, followed by factor analysis of religious beliefs and behaviors, yielding five dependent variables: (1) church activities; (2) devotional activities; (3) supernatural beliefs; (4) biblical literalism; and (5) religious exclusivity. These measures closely resemble several dependent measures used in prior embeddednessreligiosity research on Catholics and limited Protestant samples. Partly due to the complexity of the "nones" category, the religiously unaffiliated are excluded from analyses (Baker and Smith 2009). For this reason, and because many measures are oriented toward Christian Americans, I also exclude the "other religion" and Jewish respondents. ${ }^{2}$

\section{Dependent Variables}

I implemented a Varimax-rotated principal component factor analysis, revealing uncorrelated groups of conceptually distinguishable categories. Based on these analyses, four factor scales were kept and labeled as follows: church activities, devotional activities, supernatural beliefs, and religious exclusivity. Biblical literalism comes from a single item.

Church activities. Church activities is the sum of six items measuring the frequency of: service attendance, religious education programs; religious choir participation; social gatherings at church; volunteering for the community through the congregation; and volunteering for the congregation. Service attendance ranges from 0 "never" to 8 "several times a week." For religious choir, religious education programs, and social gatherings respondents were asked how often they participated in the last month. Possible responses were: not at all, 1-2 times, 3-4 times, or 5 or more times. The two remaining questions asked of respondents dealt with how many hours per month they volunteer for: their place of worship; and the community through their place of

${ }^{1}$ Though tapping the general religiousness of youth's personal networks and adult network closure, the National Survey of Youth and Religion does not ask respondents about the proportion of their friends that are part of their own church congregation. Other than the BRS, the author is not aware of any random national samples of American adults that include a measure of congregational embeddedness with these religious behavior and belief items.

${ }^{2}$ Probing for the presence of multicollinearity did not expose problematic associations. 
worship (range 1-5: none, 1-2 hours, 3-4 hours, 5-10 hours, 11 or more hours). I standardize and sum these items to create an index of church activities $(\alpha=0.83)$. Mean/SD by religious tradition: evangelical Protestant $(0.165$, 0.816); mainline Protestant $(-0.092,0.677)$; and Catholic $(-0.226,0.528)$.

Devotional activities. Following Cavendish et al.'s (1998) work on Catholics, the devotional activities scale comprises actions that are the most devotional in nature. These items load together, and were standardized prior to summing $(\alpha=0.80)$. Respondents were asked about their frequency of participation in the last month in "witnessing/sharing your faith with your friends," "witnessing/sharing your faith with strangers" (range 1-4: not at all, 1-2 times, 3-4 times, 5 or more times). ${ }^{3}$ For scripture reading, respondents were asked: "Outside of attending religious services, about how often do you read the Bible, Koran, Torah, or other sacred book?" This variable is coded as: never, less than once a year, less than once a month, less than weekly, weekly, several times a week or more often (range is 0-5). The final variable is based on a question that asked about the frequency of prayer or meditation outside of religious services (range 0-5: never, only on certain occasions, once a week or less, a few times a week, once a day, and several times a day). Devotional activities such as prayer have been found to be associated with important outcomes (Schieman 2010). In assessing the antecedents to devotional activities, it is worth noting that not unlike church participation, reading and prayer also consist of activity that may be seen by surrounding church friends. Sherkat and Cunningham (1998) suggest that seemingly private religious practices may be noticed by proximate others and can become subject to social sanctions. People often pray in public settings outside of church services, such as meals. Especially in situations of low religious diversity and dense multifunctional social ties, individuals may need to continually build up a cultural repertoire related to scriptural and religious competencies for deployment in conversational interactions. Mean/SD by religious tradition: evangelical Protestant $(0.282,0.843)$; mainline Protestant $(-0.274,0.629)$; and Catholic $(-0.294$, $0.622)$.

Supernatural beliefs. Supernatural beliefs is an additive index of six items ( $\alpha=0.93$ ) that resemble some of those in Welch's (1981) study of embeddedness and belief (see also Mencken et al. 2009). Respondents were asked about belief in the existence of: God, the Devil/Satan, heaven, hell, angels, and demons. Belief in God categories are: agnostic/atheist, belief in a higher power, belief in God with some doubts, certainty in God's existence (range is 1-4). For the remaining five belief items, response categories are: absolutely, probably, probably not, absolutely not. A majority of American Christians report

\footnotetext{
${ }^{3}$ Whether or not friends at church may always directly monitor evangelism activity, a high proportion of friends in an individual's congregation might be needed to have the social base from which to evangelize outward.
} 
"no doubts" or "absolutely" concerning the existence of God (73 percent), Satan (62 percent), heaven (71 percent), hell (61 percent), angels (69 percent), and demons (53 percent). ${ }^{4}$ Index mean/SD by religious tradition: evangelical Protestant $(3.7,0.592)$; mainline Protestant $(3.175,0.785)$; and Catholic $(3.352,0.655)$.

Biblical literalism. This belief indicator comes from a four-point measure: Which one statement comes closest to your personal beliefs about the Bible? (1) "The Bible means exactly what it says. It should be taken literally, word-for-word on all subjects"; (2) "The Bible is perfectly true, but it should not be taken literally, word-for-word. We must interpret its meaning"; (3) "The Bible contains some human error"; and (4) "The Bible is an ancient book of history and legends." Respondents could also select "don't know." Consistent with recent research (Froese et al. 2008; Stroope 2011b), I dichotomize such that $1=$ "taken literally, word-for-word" and all other responses equal 0 . Mean/SD by religious tradition: evangelical Protestant $(0.43,0.514)$; mainline Protestant $(0.105,0.297)$; and Catholic $(0.101,0.289)$.

Religious exclusivity. Similar to the exclusivity scale employed by Welch (1981), this scale taps beliefs about the exclusion of non-Judeo-Christians from heaven: Buddhists, Muslims, and nonreligious people. The BRS asked "If you believe in Heaven, how many of the following people do you think will get into heaven?." The response "none" was coded as 1 and all other responses 0 . These three items load on a single factor $(\alpha=0.95)$. For my combined measure of religious exclusivity, if all three equal 1 then religious exclusivity is equal to 1 . Combining these variables in this way produces a measure of consistent exclusivity; 13 percent of Christians believe that members of all three groups will not reach heaven. Mean/SD by religious tradition: evangelical $(0.262,0.462)$; mainline $(0.062,0.235)$; and Catholic $(0.012,0.106)$.

\section{Independent Variables}

Social embeddedness. There is an important distinction in networkreligiosity research between intratradition social ties and intracongregation social ties (Cornwall 1989:574). Despite the value of measuring an individual's degree of social encapsulation in her congregation, such a measure has yet to be used in longitudinal studies, and has been rarely included in national crosssectional surveys. In order to tap this dimension of individuals' religious lives, the BRS asked: "How many of your friends attend your place of worship?" Responses were: "none" (32 percent), "a few" (42 percent), "about half" (12 percent), "most" (13 percent), and "all" ( 2 percent). Higher scores represent greater levels of social network embeddedness in the respondent's particular religious congregation.

${ }^{4}$ Mainline Protestants and Catholics make up 21 and 22 percent of the 2007 BRS. The majority of these groups reported probably or absolutely believing in supernatural beliefs. 


\section{SOCIOLOGY OF RELIGION}

Controls. A variety of potentially confounding factors are controlled: female, age, marital status $(1=$ married), years of education (Stroope 2011a), income $^{5}$ (Baker 2008), southern residence (Rhodes 2011), and urbanicity (Stroope 2011a). Religion controls include: attendance longevity (Scheitle and Dougherty 2010), congregation size (Dougherty and Whitehead 2011), and religious affiliation, measured as a modified RELTRAD typology (table 1) (Dougherty et al. 2007; Steensland et al. 2000).

\section{RESULTS}

Models 1 and 2 of table 2 find support for hypothesis 1 (The more an individual's friendships come from his or her congregation, the more an individual will participate in religious activities). These findings constitute robust support for relationships suggested in prior work, but now in a national sample and taking into account potentially confounding factors. Is social embeddedness simply standing in for length of time at the congregation? Or is it possible that going to a small, gemeinschaft-like congregation accounts for the association between embeddedness and religious behavior? The results indicate that the answers to these questions are all no. Social embeddedness is consistently significant and positive across both sets of religious activities models, even when all religion and demographic controls are included. The positive association between social embeddedness and both religious activity outcomes is clear and consistent, confirming theory and previous research positing an embeddedness-activities relationship. Additionally, 33 percent of the variation in church activities and 35 percent of the variation in devotional activities is explained by the full models. Some differences between models are worth noting. In terms of standardized effect, social embeddedness carries the largest effect in predicting church activities $(B=0.411, p<.001)$. The second largest effect is the negative effect of Catholic affiliation $(B=-0.218$, $p<.001)$. For devotional religious activities, social embeddedness' effect size is the second largest in the model $(B=0.273, p<.001)$, ranked just after the negative effect of Catholic affiliation $(B=-0.328, p<.001)$. These models provide strong evidence that there is a powerful relationship between social embeddedness and religious activities.

Social embeddedness tells a similar story for religious belief. Previous literature expects social embeddedness to significantly affect belief. This theoretical background was expressed in hypothesis 2. Models 3 through 5 of table 2 provide support for hypothesis 2 , controlling for a variety of personal and congregational characteristics. Greater social embeddedness is associated with

\footnotetext{
${ }^{5} \mathrm{~A}$ small number of missing values on income were assigned mean income.
} 
TABLE 1 Descriptive Statistics

\begin{tabular}{|c|c|c|c|c|}
\hline Variable & Mean & SD & Minimum & Maximum \\
\hline Female & 0.550 & 0.499 & 0 & 1 \\
\hline Age & 48.177 & 17.078 & 18 & 96 \\
\hline Married & 0.637 & 0.482 & 0 & 1 \\
\hline Education & 4.180 & 1.493 & 1 & 7 \\
\hline Income & 4.260 & 1.534 & 1 & 7 \\
\hline South & 0.344 & 0.477 & 0 & 1 \\
\hline Urbanicity & 2.273 & 0.942 & 1 & 4 \\
\hline \multicolumn{5}{|l|}{ Religious tradition } \\
\hline Evangelical Protestant & 0.410 & 0.492 & 0 & 1 \\
\hline Black Protestant & 0.059 & 0.236 & 0 & 1 \\
\hline Mainline Protestant & 0.256 & 0.437 & 0 & 1 \\
\hline Catholic & 0.274 & 0.446 & 0 & 1 \\
\hline Length of time attending & 2.772 & 1.763 & 0 & 5 \\
\hline Size of congregation & 2.220 & 1.678 & 0 & 6 \\
\hline Social embeddedness & 2.113 & 1.052 & 1 & 5 \\
\hline All friends & 0.018 & 0.134 & 0 & 1 \\
\hline Most friends & 0.129 & 0.336 & 0 & 1 \\
\hline Half of friends & 0.118 & 0.323 & 0 & 1 \\
\hline A few friends & 0.418 & 0.495 & 0 & 1 \\
\hline No friends & 0.317 & 0.467 & 0 & 1 \\
\hline Church activities & -0.020 & 0.739 & -0.724 & 3.014 \\
\hline Service attendance & 4.221 & 2.802 & 0 & 8 \\
\hline Religious education & 1.629 & 1.009 & 1 & 4 \\
\hline Religious choir & 1.217 & 0.666 & 1 & 4 \\
\hline Church social gatherings & 1.543 & 0.764 & 1 & 4 \\
\hline Community volunteering through church & 0.482 & 0.954 & 0 & 4 \\
\hline Volunteering for church & 0.590 & 1.036 & 0 & 4 \\
\hline Devotional activities & -0.012 & 0.792 & -1.168 & 2.217 \\
\hline Sharing faith with friends & 1.663 & 0.909 & 1 & 4 \\
\hline Sharing faith with strangers & 1.368 & 0.715 & 1 & 4 \\
\hline Scripture reading & -0.013 & 1.000 & -1.323 & 1.576 \\
\hline Prayer frequency & 3.360 & 1.617 & 0 & 5 \\
\hline Supernatural beliefs & 3.462 & 0.717 & 1 & 4 \\
\hline God & 3.573 & 0.803 & 1 & 4 \\
\hline Satan & 3.383 & 0.897 & 1 & 4 \\
\hline Heaven & 3.595 & 0.729 & 1 & 4 \\
\hline Hell & 3.390 & 0.885 & 1 & 4 \\
\hline Angels & 3.552 & 0.770 & 1 & 4 \\
\hline Demons & 3.213 & 0.966 & 1 & 4 \\
\hline Biblical literalism & 0.253 & 0.436 & 0 & 1 \\
\hline Religious exclusivity & 0.130 & 0.340 & 0 & 1 \\
\hline Buddhists excluded & 0.175 & 0.384 & 0 & 1 \\
\hline Muslims excluded & 0.174 & 0.383 & 0 & 1 \\
\hline Nonreligious excluded & 0.231 & 0.426 & 0 & 1 \\
\hline
\end{tabular}

Source: Baylor Religion Survey (2007); data are weighted and exclude non-Christian respondents. 
TABLE 2 The Effects of Social Embeddedness on Religion Outcomes

\begin{tabular}{|c|c|c|c|c|c|c|c|c|c|c|c|c|c|c|c|}
\hline & \multicolumn{3}{|c|}{ Church activities } & \multicolumn{3}{|c|}{ Devotional activities } & \multicolumn{3}{|c|}{ Supernatural beliefs } & \multicolumn{3}{|c|}{ Biblical literalism } & \multicolumn{3}{|c|}{ Religious exclusivity } \\
\hline & \multicolumn{3}{|l|}{ M1 } & \multicolumn{3}{|l|}{ M2 } & \multicolumn{3}{|l|}{ M3 } & \multicolumn{3}{|l|}{ M4 } & \multicolumn{3}{|l|}{ M5 } \\
\hline & $b$ & SE & $B$ & $b$ & SE & $B$ & $b$ & SE & $B$ & $b$ & SE & $B$ & $b$ & SE & $B$ \\
\hline Intercept & -0.658 & $0.108^{* * *} *$ & & -0.497 & $0.112 * * *$ & & 3.590 & $0.106 * * *$ & & -0.180 & 0.445 & & -2.646 & $0.585 * * *$ & \\
\hline Female & 0.022 & 0.038 & 0.015 & 0.184 & $0.039 * * *$ & 0.115 & 0.167 & $0.037 * * *$ & 0.120 & 0.208 & 0.159 & 0.057 & -0.505 & $0.200 *$ & -0.139 \\
\hline Age & -0.002 & 0.001 & -0.039 & 0.002 & 0.001 & 0.044 & -0.004 & $0.001 * *$ & -0.090 & 0.004 & 0.005 & 0.041 & 0.004 & 0.006 & 0.036 \\
\hline Married & 0.082 & 0.043 & 0.052 & 0.056 & 0.045 & 0.033 & 0.073 & 0.043 & 0.049 & 0.300 & 0.183 & 0.079 & 0.418 & 0.243 & 0.110 \\
\hline Education & 0.027 & $0.014^{*}$ & 0.055 & 0.014 & 0.014 & 0.027 & -0.048 & $0.014 * * *$ & -0.102 & -0.141 & $0.060 *$ & -0.116 & 0.095 & 0.075 & 0.077 \\
\hline Income & -0.016 & 0.015 & -0.033 & -0.051 & $0.015 * * *$ & -0.097 & -0.023 & 0.015 & -0.048 & -0.192 & $0.062 * *$ & -0.159 & 0.035 & 0.082 & 0.029 \\
\hline South & 0.146 & $0.041 * * *$ & 0.094 & 0.152 & $0.043 * * *$ & 0.091 & 0.144 & $0.040 * * *$ & 0.099 & 0.245 & 0.165 & 0.064 & -0.164 & 0.209 & -0.043 \\
\hline Urbanicity & -0.038 & 0.022 & -0.047 & -0.021 & 0.022 & -0.024 & -0.044 & $0.021 *$ & -0.058 & -0.246 & $0.092 * *$ & -0.126 & -0.054 & 0.116 & -0.027 \\
\hline \multicolumn{16}{|c|}{ Religious tradition (ref = Evangelical Protestant) } \\
\hline Black Protestant & 0.019 & 0.086 & 0.006 & 0.232 & $0.089 * *$ & 0.069 & 0.096 & 0.085 & 0.032 & 0.027 & 0.291 & 0.004 & -1.139 & $0.468 *$ & -0.150 \\
\hline Mainline Protestant & -0.171 & $0.049 * * *$ & -0.100 & -0.493 & $0.051 * * *$ & -0.270 & -0.409 & $0.049 * * *$ & -0.255 & -1.927 & $0.235 * * *$ & -0.463 & -1.873 & $0.306 * * *$ & -0.446 \\
\hline Catholic & -0.358 & $0.047 * * *$ & -0.218 & -0.584 & $0.050 * * *$ & -0.328 & -0.324 & $0.047 * * *$ & -0.208 & -1.972 & $0.228 * * *$ & -0.487 & -3.529 & $0.529 * * *$ & -0.870 \\
\hline Length of time attending & 0.070 & $0.013 * * *$ & 0.164 & 0.043 & $0.013 * *$ & 0.095 & 0.002 & 0.013 & 0.005 & 0.016 & 0.054 & 0.015 & -0.076 & 0.072 & -0.072 \\
\hline Size of congregation & 0.011 & 0.013 & 0.026 & 0.063 & $0.014 * * *$ & 0.131 & 0.077 & $0.013 * * *$ & 0.183 & 0.072 & 0.054 & 0.066 & 0.169 & $0.066^{*}$ & 0.154 \\
\hline Social embeddedness & 0.288 & $0.020 * * *$ & 0.411 & 0.209 & $0.021 * * *$ & 0.273 & 0.142 & $0.020 * * *$ & 0.214 & 0.460 & $0.079 * * *$ & 0.268 & 0.402 & $0.100 * * *$ & 0.234 \\
\hline$R^{2}$ & 0.328 & & & 0.353 & & & 0.261 & & & 0.316 & & & 0.281 & & \\
\hline$N$ & 1,068 & & & 1,091 & & & 1,062 & & & 1,126 & & & 1,037 & & \\
\hline
\end{tabular}

Source: Baylor Religion Survey (2007).

$*_{p}<.05 ; *^{*} p<.01 ; * * *_{p}<.001$, two-tailed test. 
increased levels of all forms of religious belief examined here. These models also explain a considerable degree of variation in belief outcomes (supernatural beliefs $=26$ percent, biblical literalism $=32$ percent, religious exclusivity $=28$ percent). In terms of standardized effects, embeddedness carries the second largest effect $(B=0.214, p<.001)$ on supernatural beliefs, slightly smaller than the negative effect of mainline Protestant affiliation $(B=-0.255$, $p<.001)$. Social embeddedness has the third largest effect $(B=0.268$, $p<.001$ ) in the model predicting biblical literalism (the negative effects of mainline Protestant and Catholic affiliation are larger). ${ }^{6}$ Finally, after mainline Protestant and Catholic affiliations, social embeddedness has the third largest standardized coefficient $(B=0.234, p<.001)$ among predictors of religious exclusivity. In sum, social embeddedness is positively correlated with these three measures of religious belief; in addition, the effects of embeddedness are robust to the inclusion of important personal and congregational factors. ${ }^{7}$

Hypothesis 3 predicted that the effects of social embeddedness on religiosity would be stronger for evangelicals and Black Protestants as compared to mainline Protestants or Catholics. This hypothesis found some support in the case of religious activities, but no support in the case of religious beliefs. Table 3 presents the results of the affiliation-by-embeddedness interaction models. Model 1 predicts supernatural beliefs; the Catholic-by-embeddedness interaction is negative and significant. Other interactions do not reach statistical significance. This model shows that the slope of the effect of embeddedness on supernatural beliefs is no different between Protestants. However, the negative Catholic interaction term indicates that the slope of embeddedness for Catholics is flatter in comparison to Protestants. Figure 1 depicts this difference. The graph shows that social embeddedness has a positive effect on supernatural beliefs for everyone, but its effect is stronger for those embedded in Protestant churches. At the lowest level of embeddedness, there is no significant difference between Protestants and Catholics. But a gap between Protestants' and Catholics' supernatural beliefs emerges and widens as people in both groups become more socially embedded in their congregations. Highly embedded Catholics show an increase in church activities compared to less embedded Catholics, but highly embedded Protestants clearly show a bigger jump in church activities compared to less embedded Protestants.

${ }^{6}$ SAS computes standardized coefficients for logistic regression using the logit distribution's standard deviation $\left(\pi^{2} / 3\right)$. Although interpreting standardized coefficients is difficult, they are useful in comparing the effects of continuous predictors to those of dummy variables within the same model (see Pampel 2000:72-73).

${ }^{7}$ Political identity was controlled in separate models (not shown) adjusting the ranking of embeddedness' standardized effects: church activities (unchanged); devotional activities (unchanged); Christian beliefs (4th); biblical literalism (4th); and exclusivity (5th). 
TABLE 3 The Effects of Social Embeddedness and Religious Tradition on Religion Outcomes

\begin{tabular}{|c|c|c|c|c|c|c|c|c|c|c|c|c|c|c|c|}
\hline & \multicolumn{3}{|c|}{ Church activities } & \multicolumn{3}{|c|}{ Devotional activities } & \multicolumn{3}{|c|}{ Supernatural beliefs } & \multicolumn{3}{|c|}{ Biblical literalism } & \multicolumn{3}{|c|}{ Religious exclusivity } \\
\hline & \multicolumn{3}{|l|}{ M1 } & \multicolumn{3}{|l|}{ M2 } & \multicolumn{3}{|l|}{ M3 } & \multicolumn{3}{|l|}{ M4 } & \multicolumn{3}{|l|}{ M5 } \\
\hline & $b$ & SE & $B$ & $b$ & SE & $B$ & $b$ & SE & $B$ & $b$ & SE & $B$ & $b$ & SE & $B$ \\
\hline \multicolumn{16}{|l|}{ Evangelical (ref.) } \\
\hline Black Protestant & 0.339 & 0.220 & 0.107 & 0.651 & $0.219 * *$ & 0.193 & 0.400 & 0.210 & 0.135 & -0.218 & 0.749 & -0.029 & -3.008 & $1.457^{*}$ & -0.396 \\
\hline Mainline Prot. & -0.067 & 0.105 & -0.039 & -0.293 & $0.111 * *$ & -0.160 & -0.479 & $0.105^{* * *}$ & -0.299 & -1.920 & $0.548 * * *$ & -0.461 & -2.509 & $0.753 * * *$ & -0.598 \\
\hline Catholic & 0.025 & 0.101 & 0.015 & -0.327 & $0.107 * * *$ & -0.184 & -0.261 & 0.102 & -0.168 & -1.692 & $0.507 * * *$ & -0.418 & -2.953 & $1.245^{*}$ & -0.728 \\
\hline $\begin{array}{l}\text { Social embeddedness } \\
\text { Interactions }\end{array}$ & 0.353 & $0.027 * * *$ & 0.503 & 0.271 & $0.029 * * *$ & 0.354 & 0.149 & $0.028^{* * *}$ & 0.225 & 0.477 & $0.102 * * *$ & 0.278 & 0.348 & $0.110 * *$ & 0.203 \\
\hline $\begin{array}{l}\text { Black Protestant } \times \text { social } \\
\text { embeddedness }\end{array}$ & -0.147 & 0.094 & -0.107 & -0.196 & $0.094 *$ & -0.134 & -0.139 & 0.089 & -0.110 & 0.114 & 0.319 & 0.035 & 0.712 & 0.488 & 0.219 \\
\hline $\begin{array}{l}\text { Mainline Protestant } \times \text { social } \\
\text { embeddedness }\end{array}$ & -0.045 & 0.045 & -0.061 & -0.095 & $0.048^{*}$ & -0.120 & 0.035 & 0.045 & 0.051 & -0.004 & 0.204 & -0.002 & 0.259 & 0.264 & 0.147 \\
\hline $\begin{array}{l}\text { Catholic } \times \text { social } \\
\text { embeddedness }\end{array}$ & -0.181 & $0.043 * * *$ & -0.272 & -0.122 & $0.046 * *$ & -0.167 & -0.029 & 0.043 & -0.046 & -0.111 & 0.184 & -0.068 & -0.221 & 0.472 & -0.136 \\
\hline$R^{2}$ & 0.339 & & & 0.358 & & & 0.262 & & & 0.316 & & & 0.286 & & \\
\hline$N$ & 1,068 & & & 1,091 & & & 1,062 & & & 1,126 & & & 1,037 & & \\
\hline
\end{tabular}

Note: Models control female, age, married, education, income, South, urbanicity, length of time attending, and size of congregation; results suppressed for brevity.

Source: Baylor Religion Survey (2007).

$*_{p}<.05 ; * * p<.01 ; * * * p<.001$, two-tailed test. 
FIGURE 1. The Influence of Social Embeddedness and Religious Tradition on Church Activities.

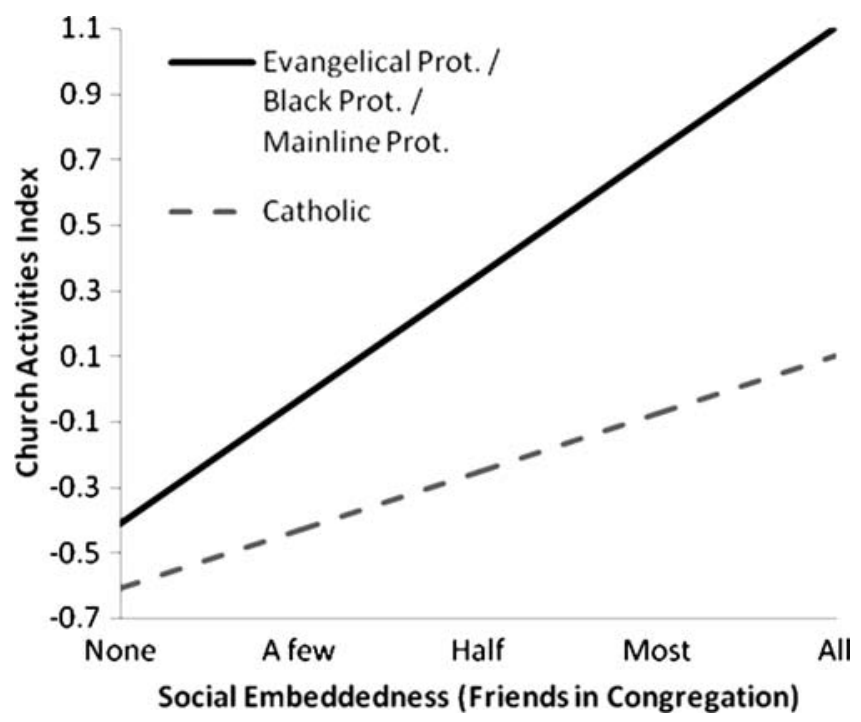

FIGURE 2. The Influence of Social Embeddedness and Religious Tradition on Devotional Activities.

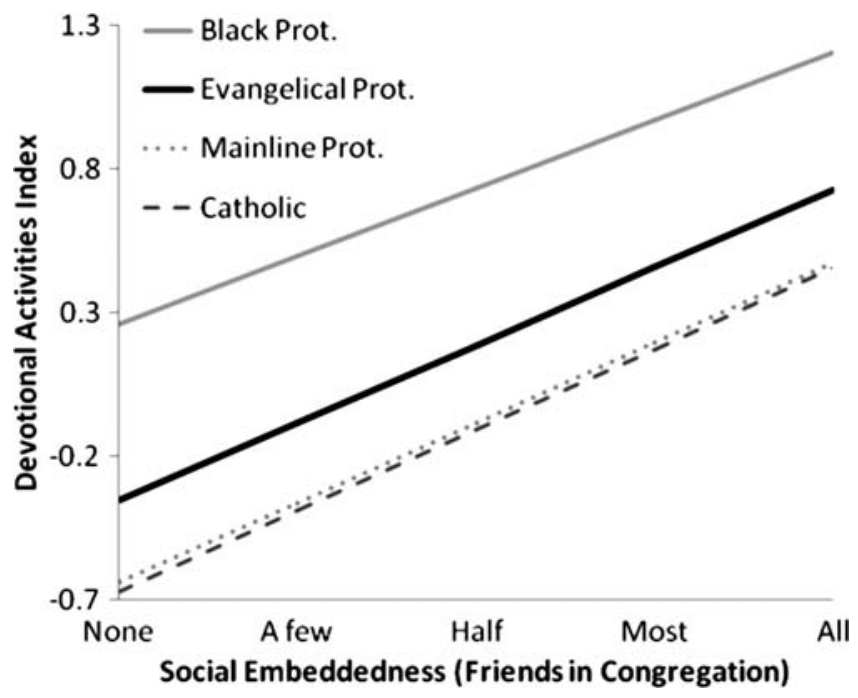

Turning to model 2, all affiliation-by-embeddedness interaction effects on devotional activities are significant. Unlike model 1, in model 2 all of the lower-order religious tradition dummy variables are also significant, suggesting not simply different embeddedness slopes, but also significantly different levels of devotional activities between traditions for persons at the lowest level of embeddedness. These differences between traditions are what is most visible in 
figure 2. Again, increased social embeddedness is related to increased devotional activities for all traditions. The effect of embeddedness is slightly stronger for evangelicals and slightly weaker for other traditions but these are not large differences in how embeddedness operates for different traditions. As mentioned above, the main things to note are the gaps between traditions and that these gaps remain substantively unchanged as persons become more socially embedded. For Black Protestants, the embeddedness interaction term is negative, indicating a flatter slope, but the slope is only slightly flatter. What is most apparent is the overall higher level of devotional activities for Black Protestants at any level of embeddedness. Although the effect of embeddedness is steepest for evangelicals, it remains closer to mainline Protestants and Catholics even at high levels of embeddedness. Social embeddedness is associated with the same change in higher devotional activities for mainline Protestant and Catholic persons, but their levels always remain just as far below evangelicals and Black Protestants no matter the level of embeddedness. No significant affiliation-by-embeddedness interactions were detected for religious beliefs. Taken together, the fact that the differences in slopes predicting devotional activities and all beliefs are not substantively or statistically significant points to the consistency of social embeddedness' strong positive relationship with religiosity in all of these Christian traditions. Illustratively, figure 2 shows that highly embedded Catholics or mainline Protestants engage in devotional activities with roughly the same frequency as Black Protestants at low levels of embeddedness. The same Catholics or mainline Protestants are clearly more devout than low-embeddedness evangelicals.

\section{Supplemental Analyses}

Because of the possibility that some items comprising the dependent composite measures may be most applicable to evangelical Protestants, I conducted all regressions separately within America's three largest religious traditions: evangelical Protestants, Catholics, and mainline Protestants (results not shown). All models included controls identical to the full models in table 2. These ancillary analyses reveal that social embeddedness is positive, significant, and carries the largest standardized effect on both church activities and devotional activities in all three religious tradition subsamples. With spiritual beliefs or biblical literalism as response variables, social embeddedness is positive, significant and the largest independent variable in the evangelical and mainline Protestant samples. In the sample restricted to Catholics, embeddedness has the third largest effect $(B=0.182, p<.01)$ on spiritual beliefs after the negative effect of educational attainment $(B=-0.246, p<.001)$ and the positive effect of church size $(B=0.230, p<.001)$. Social embeddedness is nonsignificant in its association with biblical literalism in the Catholic sample, but since nonsignificance may be due to subsample size, I note that embeddedness' standardized coefficient $(B=0.175, p=.096)$ is the third largest in the model after income $(B=-0.260, p<.05)$ and congregation size $(B=0.186$, 
$p=.139)$. Finally, in predicting religious exclusivity, social embeddedness carries the second largest effect $(B=0.203, p<.01)$ in the evangelical-only model after the positive effect of church size $(B=0.234, p<.001)$. In the mainline Protestant sample, embeddedness' standardized coefficient $(B=$ $0.768, p<.001)$ ranks second in size after the negative effect of southern residence $(B=-0.793, p<.01)$. Among Catholics, social embeddedness has no statistically significant influence on religious exclusivity; in terms of size, it ranks 7 th out of 10 standardized coefficients.

In an effort to explore how different categories within the social embeddedness measure may be especially important for religion outcomes, I re-estimated all models in table 2 using a series of social embeddedness dummy variables instead of the ordinal variable. "All friends" was made the reference category. For the church activities outcome, "half of friends" was marginally nonsignificant $(p=.06)$ and "a few friends" and "no friends" were significant and negative in reference to "all friends." For devotional activities, all embeddedness categories were significant and negative. For supernatural beliefs, people with "no friends" at church espouse significantly fewer beliefs than people with "all friends" at church. When "no friends" is the reference, all four remaining embeddedness categories are significant and positive. Having some as opposed to no friends at church appears to be the important point associated with supernatural beliefs. For biblical literalism, people in descending categories of social embeddedness are less likely to be literalists as compared to people with "all friends" at church (however, the "most friends" category did not reach statistical significance at $p=.065$ ). Turning to religious exclusivity, no category was significantly different from "all friends." But with "no friends" set as the reference category, people in all but one embeddedness category are more likely to affirm religious exclusivity. This indicates that having some as opposed to no friends at church is largely what makes the difference for espousing religious exclusivity. In terms of the magnitude of effect, in no instances were the embeddedness categories small in terms of their standardized effects; in most instances, they carried the largest standardized effects in models.

I also explored several possible interaction effects on all religion outcomes. Social embeddedness $\times$ urbanicity was nonsignificant for all religion outcomes. Social embeddedness $\times$ service attendance was nonsignificant for all religion outcomes except supernatural beliefs. However, graphing the interactive effects of embeddedness and service attendance on supernatural beliefs revealed that this interaction was not substantively significant.

To investigate findings further, I duplicate analyses using the 1998 General Social Survey using similar variables and controls where possible; results led to similar conclusions as those using the BRS. One possible limitation of the BRS' embeddedness measure is that it may not be as valid and reliable when compared to a congregational friendship measure I constructed from the GSS: a measure of a person's embeddedness within the respondent's congregation using an item that asked for information about the respondent's five closest 
friends, including whether each person attends the respondent's congregation. Since not all respondents had five friends, I take the mean number of close friends in the respondent's congregation based on the number of friends for which the respondent reported information. This embeddedness measure is positively associated with all religious activities composite indicators I constructed: public religious activities (ATTEND, RELACTIV, VOLWKREL $[\alpha=$ 0.80 ]; $b=0.735, p<.0001$ ); private religious activities (READBIBL, PRAY, PRIVPRAY, PRAYFREQ $[\alpha=0.86] ; b=0.295, p<.05)$; religious activity hours (logged) (RELHRS1, RELHRS2 $[\alpha=0.66] ; b=0.715, p<.0001$ ). In terms of religious belief, social embeddedness was not significantly associated with biblical literalism. Religious traditions-by-embeddedness interaction effects were all nonsignificant except a Catholic $\times$ embeddedness interaction $(b=-0.830$, $p<.05)$ predicting private religious activities. The slope of the effect of embeddedness on this outcome is significantly flattened for Catholics compared to evangelicals. This interaction is consistent with the Catholic interaction seen in the BRS findings. Also in keeping with the BRS results, probing other interactions (urbanization $\times$ embeddedness, church attendance $\times$ embeddedness) yielded nonsignificant interactions. Overall, these ancillary GSS analyses are in line with the BRS findings.

\section{DISCUSSION AND CONCLUSIONS}

Prompted by the classical centrality of social networks in religious life, this study has sought to contribute to the literature on social networks and religion by developing theoretically based hypotheses that have rarely been put to an empirical test. The study has also taken advantage of a new national survey with more comprehensive religion items than have previously been available. By controlling for important religiosity predictors in the sociology of religion and using two national datasets of various religious traditions, this study is the first to have assessed the extent to which social embeddedness in a religious congregation is associated with both participation in religious activities and belief in religious doctrines.

In support of previous literature emphasizing the importance of social embeddedness for religiosity, I find powerful and robust relationships between embeddedness in religious congregations and all indicators of religious activity and belief. Furthermore, these social embeddedness effects are among the top three largest effects for all outcomes and in the case of church activities, embeddedness is the most powerful predictor. This ranking of effect size generally holds for all traditions but is somewhat different for Catholics, a finding I will return to later. Another finding of this study is that when it comes to church activities, social embeddedness' effects are not different among Protestants, but are attenuated by Catholic affiliation. Overall, I find strong indication that greater embeddedness in a religious congregation is a major 
factor associated with multiple dimensions of religiosity. These findings are particularly useful since embeddedness' effects on religiosity are subjected to a variety of model specifications and important control variables. Also, few recent national datasets permit this robust of an assessment using individual and congregational control variables along with a variety of composite religiosity outcome measures.

Prior theory expects that religious social networks promote participation in religious activity. Research specifically on embeddedness among friendships in a congregation accords with this theoretical background, indicating that embeddedness increases religious participation (e.g., Stark and Bainbridge 1985). The present study's findings expand the previous embeddednessreligious participation results, showing embeddedness' positive and consistent relationship with religious activity, now in a national sample of various religious traditions. This relationship holds, even when control variables are in place: both sociodemographic and religion controls such as religious tradition, congregation size, and attendance longevity. It is important to stress the addition of these controls because they were excluded in previous embeddednessreligiosity research, leaving open the possibility that embeddedness might have stood in for another variable such as the length of time a person attended her church. The present study extends the embeddedness-religiosity literature by accounting for such possibilities. After controlling for the effects of potentially confounding factors, we can be more confident of a firm relationship between embeddedness and these measures of participation in religious activities.

This study's embeddedness-belief results also extend prior work. The present study's data from a national sample show that social embeddedness is robustly associated with religious belief. In the face of broad social mores concerning pluralism and tolerance, a plausible social mechanism for traditional religious belief (e.g., belief in the existence of in hell, biblical literalism, or exclusivism) is that social embeddedness serves to maintain belief by continually reinforcing for the individual that she is not alone in her belief in heaven's "narrow gate" or the literal reading of one scriptural revelation. Regardless of the validity of this possible explanation, the empirical findings presented here are valuable because they bolster confidence in the theorized embeddedness-belief connection and also point to the need for ongoing research on the role of congregational social networks in other religious (Baker and Draper 2010), economic (Froese and Bader 2008) and sexual beliefs (Whitehead 2010, forthcoming).

One interesting finding in these data is that there appears to be a somewhat stronger relationship between social embeddedness and religious activity than embeddedness and religious belief. One plausible interpretation for why the embeddedness-activity relationship is consistently stronger than that of embeddedness-belief is that when a group's networks are more closed (Coleman 1990) and a group member's personal ties are consolidated, the group can better monitor and sanction the individual based on outward 
behaviors; behaviors are more easily detectable than beliefs. Put differently, a person might be able to hide her beliefs from friends, but not necessarily her behaviors. Religious actions such as attending educational classes, reading scripture, volunteering, and musical expression are often behavior subject to friends' direct surveillance (a person either attends or is absent), and so when participation wanes, network attention is induced, producing more air-tight social pressure when friends are clustered in a single congregation (Blau and Schwartz 1984)_-"Do you know why Jessica didn't come this week? We should call her."

Even religious activities that can be done individually, and are often considered private, may become subject to monitoring, solidarity rewards, and social reproof from others (Sherkat and Cunningham 1998). For example, scripture reading by definition requires some sort of visible marker-a physical text. Scriptures usually have a distinct appearance and so may be observed by others as they are handled. Such physical markers do not go unnoticed and appreciated by friends familiar with the scriptures of their church. Some religious groups also assign weekly or daily scripture reading as part of their educational programming. Solidarity incentives are in play when members report back to the group regarding the enrichment gained from reading the religious text. A vague report made up on the spot will not necessarily stand in place of an account of enrichment drawn from marinating in scripture or prayer. The somewhat weaker and less consistent relationship between embeddedness and religious belief may be because beliefs about God, heaven, hell, angels, and demons are simply assumed or peripheral to conversations in congregationbased friendship interactions. Views of the Bible or the specifics of soteriology are also arguably not a common topic of conversation, even in conservative churches. Church gossip or "prayer requests" may be more common conversation pieces (Wuthnow 2011). Matters of religious belief may be assumed and left unprobed. Nevertheless, a robust embeddedness-belief association is evident in this study's data; it is simply not as strong as is the case with religious activity. Taken together, the above combined theoretical background and empirical findings underscore the need for the broader incorporation of social embeddedness measures in studies of religion.

The interactive effects of religious tradition and social embeddedness are also worthy of discussion. The relationship between embeddedness and church activities is stronger for evangelical Protestants in comparison to Catholics, but not stronger in comparison to mainline or Black Protestants. Although embeddedness' effects are always positive, Catholic congregations receive diminishing participation returns for the embeddedness of their members in comparison to Protestant congregations. This indicates that although American religion may be characterized as de facto congregationalism (Warner 1994), this fact should not be overstated. Protestants appear to be more congregational than Catholics and embeddedness seems to align Protestants much more strongly to their congregationalism as compared to Catholics. For this 
study's other outcomes, negligible or no differences were detected in terms of additive tradition-by-embeddedness effects. For all traditions, social embeddedness has the same substantive effects on devotional activities and religious beliefs. This finding is important because it implies that social embeddedness may have an equally positive influence on these religiosity outcomes and that this applies to all of America's major Christian traditions. Another interpretation of this finding is that it suggests that in terms of personal religiosity, it is not enough to know whether a person is evangelical or mainline Protestant or Catholic. Rather, we must also know about a person's plausibility structure, and especially his level of social embeddedness in a religious congregation. For example, Catholics immersed in friendships at their parish appear to be more devout than less immersed evangelical Protestants.

Though I have sought to clarify the relationship between social embeddedness and religious belief and participation, in the end, this study is limited in two major ways. First, the cross-sectional data do not allow variables to be ordered in time and although the theoretical literature reviewed is more weighted toward the analyses undertaken, it is conceivable that some of the effects discussed might run in the opposite direction. For instance, rather than embeddedness affecting religiosity, religiously similar people may gravitate toward the same congregations and friendship circles. But in reality, it is likely that embeddedness and religiosity influence each other reciprocally, and given the complexity of the dynamics that could produce such effects, it might be difficult to unravel causal order, even with panel data. Despite this limitation, the questions raised in this study are worth examining and the distinctions drawn by the results seem valuable. Second, the most proximate mechanisms linking embeddedness with religious behavior, monitoring and sanctions, are left theorized and approximated, but not specifically tested. This study has only added to existing groundwork for understanding social embeddedness' relationship with religious behavior and belief, but it has not revealed the particular reasons for associations. For example, this study sheds little light on the kinds of social sanctions that are most powerful in motivating religiosity. Are they negative or positive sanctions? The degree to which emotional rewards or penalties in an embedded environment account for heightened religiosity remains uncertain. Research on images of God suggests that it is not belief in a negatively sanctioning God but rather belief in a relationally engaged or intimate God that heightens religiosity (Froese and Bader 2007, 2010). Future research could test whether the same pattern holds true for positive engagement with congregational friends rather than negative sanctions from congregational friends. More refined social sanction measures would be needed for future researchers to adequately address this issue. Survey research could develop questions that measure the degree that a worshipper feels surveiled and sanctioned and the degree that her friends feel that they surveil and sanction her. Qualitative research would also be well suited for this line of inquiry. A related advance in measurement could be made in congregational data collection: 


\section{SOCIOLOGY OF RELIGION}

religiosity traits of respondents that identify each other as friends in a congregation could be used to measure the religiosity of the congregational network in which a person is embedded.

The data presented here afford a step forward in understanding connections between congregation-based social networks and the religiosity of American Christians, which subsequent research can extend. Researchers should continue to examine how congregational encapsulation might be better measured and modeled for the American adult population including America's non-Christians. Further examination of the connection between social embeddedness and religiosity will aid in fleshing out a richer portrait of the social structural sources of religiosity. For the present, this study has added evidence that people who are more immersed in friendships at church also exhibit greater religiosity.

\section{ACKNOWLEDGMENTS}

The author wishes to thank Chris Bader, Joseph Baker, Phillip Connor, Kevin Dougherty, Scott Draper, Paul Froese, Carson Mencken, Jerry Park, Andrew Whitehead, anonymous reviewers, and the Editor of Sociology of Religion for helpful comments on this work. The Baylor Religion Surveys are supported by the John T. Templeton Foundation. An earlier version of this manuscript was presented at the Association for the Sociology of Religion 2009 annual meeting in San Francisco, CA, USA.

\section{REFERENCES}

Abel, Andrew. 2006. "Favor Fishing and Punch-Bowl Christians: Ritual and Conversion in a Chinese Protestant Church." Sociology of Religion 67, no. 2:161-78.

Adamczyk, Amy. 2009. "Socialization and Selection in the Link between Friends' Religiosity and the Transition to Sexual Intercourse." Sociology of Religion 70, no. $1: 5-27$

American Association for Public Opinion Research. 2008. "Do Response Rates Matter?" http://www.aapor.org (retrieved November 23, 2010).

Ammerman, Nancy Tatom. 2005. Pillars of Faith: American Congregations and Their Partners. Berkeley: University of California Press.

Bader, Christopher D., and Scott A. Desmond. 2006. "Do as I Say and as I Do: The Effects of Consistent Parental Beliefs and Behaviors upon Religious Transmission." Sociology of Religion 67, no. 3:313-29.

Bader, Christopher D., F. Carson Mencken, and Paul Froese. 2007. "American Piety 2005: Content and Methods of the Baylor Religion Survey." Journal for the Scientific Study of Religion 46, no. 4:447-63.

Baker, Joseph O. 2008. "An Investigation of the Sociological Patterns of Prayer Frequency and Content." Sociology of Religion 69, no. 2:169-85. 
Baker, Joseph O, and Draper Scott. 2010. Diverse Supernatural Portfolios: Certitude, Exclusivity, and the Curvilinear Relationship Between Religiosity and Paranormal Beliefs. Journal for the Scientific Study of Religion 49, no. 3:413-424.

Baker, Joseph O'Brian, and Buster Smith. 2009. "None Too Simple: Examining Issues of Religious Nonbelief and Nonbelonging in the United States." Journal for the Scientific Study of Religion 48, no. 4:719-33.

Barrett, Jennifer B., Jennifer Pearson, Chandra Muller, and Kenneth A. Frank. 2007. "Adolescent Religiosity and School Contexts." Social Science Quarterly 88, no. 4:1024-37.

Berger, Peter L. 1967. The Sacred Canopy: Elements of a Sociological Theory of Religion. Garden City, NY: Doubleday.

Blau, Peter Michael, and Joseph E. Schwartz. 1984. Crosscutting Social Circles: Testing a Macrostructural Theory of Intergroup Relations. New Brunswick: Academic Press.

Burkett, Steven R., and Bruce O. Warren. 1987. "Religiosity, Peer Associations, and Adolescent Marijuana Use: A Panel Study of Underlying Causal Structures." Criminology 25, no. 1:109-32.

Burt, Ronald S., and Marc Knez. 1995. "Kinds of Third-Party Effects on Trust." Rationality and Society 7, no. 3:255-92. Retrieved April 29, 2011.

Cavendish, James C., Michael R. Welch, and David C. Leege. 1998. "Social Network Theory and Predictors of Religiosity for Black and White Catholics: Evidence of a 'Black Sacred Cosmos'?" Journal for the Scientific Study of Religion 37, no. 3:397-410.

Coleman, James Samuel. 1990. Foundations of Social Theory. Cambridge, MA: Harvard University Press.

Collins, Randall. 1997. "Stark and Bainbridge, Durkheim and Weber: Theoretical Comparisons." In Rational Choice Theory and Religion: Summary and Assessment, edited by Lawrence A. Young, 161-80. New York: Routledge.

Cornwall, Marie. 1989. "The Determinants of Religious Behavior: A Theoretical Model and Empirical Test." Social Forces 68, no. 2:572-92.

Dougherty, Kevin D., and Andrew L. Whitehead. 2011. "A Place to Belong: Small Group Involvement in Religious Congregations." Sociology of Religion 72, no. 1:91-111.

Dougherty, K. D., B. R. Johnson, and E. C. Polson. 2007. "Recovering the Lost: Remeasuring US Religious Affiliation." Journal for the Scientific Study of Religion 46, no. 4:483-99.

Durkheim, Emile. 1912. The Elementary Forms of Religious Life. Free Press.

Ellison, Christopher G. 1995. "Rational Choice Explanations of Individual Religious Behavior: Notes on the Problem of Social Embeddedness." Journal for the Scientific Study of Religion 34, no. 1:89-97.

Ellison, Christopher G., and Darren E. Sherkat. 1995. "The 'Semi-involuntary Institution' Revisited: Regional Variations in Church Participation among Black Americans." Social Forces 73, no. 4:1415-37. Retrieved April 22, 2011.

Emerson, Michael O., and Christian Smith. 2000. Divided by Faith: Evangelical Religion and the Problem of Race in America. USA: Oxford University Press.

Emirbayer, Mustafa, and Jeff Goodwin. 1994. "Network Analysis, Culture, and the Problem of Agency." American Journal of Sociology 99, no. 6:1411-54.

Erickson, Joseph A. 1992. "Adolescent Religious Development and Commitment: A Structural Equation Model of the Role of Family, Peer Group, and Educational Influences." Journal for the Scientific Study of Religion 31, no. 2:131-52. Retrieved April 29, 2011.

Froese, Paul, and Christopher D. Bader. 2007. "God in America: Why Theology Is Not Simply the Concern of Philosophers." Journal for the Scientific Study of Religion 46, no. 4:465-81. 
2008. Unraveling Religious Worldviews: The Relationship between Images of God and Political Ideology in a Cross-Cultural Analysis. The Sociological Quarterly 49, no. 4:689-718.

- 2010. America's Four Gods: What We Say about God and What That Says about Us. New York: Oxford University Press.

Froese, Paul, Christopher Bader, and Buster Smith. 2008. "Political Tolerance and God's Wrath in the United States." Sociology of Religion 69, no. 1:29-44.

Granovetter, Mark S. 1973. "The Strength of Weak Ties." American Journal of Sociology 78, no. $6: 1360-80$.

Granovetter, Mark. 1992. "Economic Institutions as Social Constructions: A Framework for Analysis." Acta Sociologica 35, no. 1:3-11. Retrieved April 29, 2011.

Hammond, Phillip E. 1992. Religion and Personal Autonomy: The Third Disestablishment in America. Columbia: University of South Carolina Press.

Hechter, Michael. 1988. Principles of Group Solidarity. Berkeley: University of California Press.

Hunter, James Davison. 1981. "Operationalizing Evangelicalism: A Review, Critique \& Proposal." Sociology of Religion 42, no. 4:363-72.

Iannaccone, Lawrence R. 1994. "Why Strict Churches Are Strong." American Journal of Sociology 99, no. 5:1180-211.

Kadushin, Charles, and Laurence Kotler-Berkowitz. 2006. "Informal Social Networks and Formal Organizational Memberships among American Jews: Findings from the National Jewish Population Survey 2000-01." Sociology of Religion 67, no. 4:465-85.

Kalir, B. 2009. "Finding Jesus in the Holy Land and Taking Him to China: Chinese Temporary Migrant Workers in Israel Converting to Evangelical Christianity." Sociology of Religion 70, no. 2:130-56.

Kane, D., and J. M. Park. 2009. "The Puzzle of Korean Christianity: Geopolitical Networks and Religious Conversion in Early Twentieth-Century East Asia." American Journal of Sociology 115, no. 2:365-404.

Lim, Chaeyoon, and Robert D. Putnam. 2010. "Religion, Social Networks, and Life Satisfaction." American Sociological Review 75, no. 6:914-33.

Lofland, John, and Rodney Stark. 1965. "Becoming a World-Saver: A Theory of Conversion to a Deviant Perspective." American Sociological Review 30, no. 6:862-75. Retrieved February 13, 2011.

Marsden, Peter V., and Noah E. Friedkin. 1993. "Network Studies of Social Influence." Sociological Methods EF Research 22, no. 1:127-51. Retrieved April 29, 2011.

Martin, T. F., J. M. White, and D. Perlman. 2003. "Religious Socialization: A Test of the Channeling Hypothesis of Parental Influence on Adolescent Faith Maturity." Journal of Adolescent Research 18, no. 2:169-87. Retrieved April 29, 2011.

McAdam, Doug. 1986. "Recruitment to High-Risk Activism: The Case of Freedom Summer." The American Journal of Sociology 92, no. 1:64-90. Retrieved April 29, 2011.

McIntosh, William Alex, Dianne Sykes, and Karen S. Kubena. 2002. "Religion and Community among the Elderly: The Relationship between the Religious and Secular Characteristics of Their Social Networks." Review of Religious Research 44, no. 2:109-25.

Mears, Daniel P., and Christopher G. Ellison. 2000. "Who Buys New Age Materials? Exploring Sociodemographic, Religious, Network, and Contextual Correlates of New Age Consumption." Sociology of Religion 61, no. 3:289-313.

Mencken, F. Carson, Christopher D. Bader, and Ye Jung Kim. 2009. "Round Trip to Hell in a Flying Saucer: The Relationship between Conventional Christian and Paranormal Beliefs in the United States." Sociology of Religion 70, no. 1:65-85. 
Moody, James, and Pamela Paxton. 2009. "Building Bridges." American Behavioral Scientist 52, no. 11:1491-506.

Nonnemaker, James, Clea A. McNeely, and Robert Wm Blum. 2006. "Public and Private Domains of Religiosity and Adolescent Smoking Transitions." Social Science 83 Medicine 62, no. 12:3084-95.

Olson, Daniel V. A. 1989. "Church Friendships: Boon or Barrier to Church Growth?" Journal for the Scientific Study of Religion 28, no. 4:432-47.

Pampel, Fred C. 2000. Logistic Regression: A Primer. Thousand Oaks, CA: Sage Publications.

Polson, Edward C. 2008. "The Inter-Organizational Ties That Bind: Exploring the Contributions of Agency-Congregation Relationships." Sociology of Religion 69, no. 1:45-65.

Putnam, Robert D., and David E. Campbell. 2010. American Grace: How Religion Divides and Unites Us. Simon \& Schuster.

Regnerus, Mark D., Christian Smith, and Brad Smith. 2004. "Social Context in the Development of Adolescent Religiosity." Applied Developmental Science 8, no. 1:27-38.

Rhodes, Jeremy. 2011. "Choosing Sides: An Exploration of Role Conflict among Evangelical Democrats." Sociology of Religion 72, no. 1:28-49. Retrieved April 22, 2011.

Roberts, Michael K., and James D. Davidson. 1984. "The Nature and Sources of Religious Involvement." Review of Religious Research 25, no. 4:334-50. Retrieved April 29, 2011.

Scheitle, C. P., and Kevin Dougherty. 2010. "Race, Diversity, and Membership Duration in Religious Congregations." Sociological Inquiry 80, no. 3:405-23.

Scheitle, Christopher P., and Roger Finke. 2008. "Maximizing Congregational Resources: Selection Versus Production." Social Science Research 37, no. 3:815-27.

Schieman, Scott. 2010. "Socioeconomic Status and Beliefs about God's Influence in Everyday Life." Sociology of Religion 71, no. 1:25-51.

Sherkat, Darren E., and Shannon A. Cunningham. 1998. "Extending the Semi-Involuntary Institution: Regional Differences and Social Constraints on Private Religious Consumption among African Americans." Journal for the Scientific Study of Religion 37, no. 3:383-96.

Singer, Eleanor. 2006. "Special Issue on Nonresponse Bias in Household Surveys." Public Opinion Quarterly 70, no. 5:639-810.

Smilde, D. 2005. "A Qualitative Comparative Analysis of Conversion to Venezuelan Evangelicalism: How Networks Matter." American Journal of Sociology 111, no. 3:757-96.

Smith, Christian, Michael Emerson, Sally Gallagher, Paul Kennedy, and David Sikkink. 1998. American Evangelicalism: Embattled and Thriving. Chicago: University of Chicago Press.

Snow, David A., Louis A. Zurcher, and Sheldon Ekland-Olson. 1980. "Social Networks and Social Movements: A Microstructural Approach to Differential Recruitment." American Sociological Review 45, no. 5:787-801.

Stark, Rodney. 1995. "Reconstructing the Rise of Christianity: The Role of Women." Sociology of Religion 56, no. 3:229.

Stark, Rodney, and William Sims Bainbridge. 1980. "Networks of Faith: Interpersonal Bonds and Recruitment to Cults and Sects." American Journal of Sociology 85, no. 6:1376-95.

- 1985. Future of Religion: Secularization, Revival and Cult Formation. Later Printing. Berkeley: University of California Press.

Stark, Rodney, and Charles Glock. 1968. American Piety: The Nature of Religious Commitment. Berkeley: University of California Press. 


\section{SOCIOLOGY OF RELIGION}

Steensland, Brian, Jerry Z. Park, Lynn D. Robinson, W. Bradford Wilcox, and Robert D. Woodberry. 2000. "The Measure of American Religion: Toward Improving the State of the Art." Social Forces 79, no. 1:291-318.

Stroope, Samuel. 2011a. "Caste, Class, and Urbanization: The Shaping of Religious Community in Contemporary India." Social Indicators Research First published January 21, 2011, doi:10.1017/s.11205-011-9784-y.

- 2011b. "Education and Religion: Individual, Congregational, and Cross-Level Interaction Effects on Biblical Literalism." Social Science Research 40, no. 6:1478-1493.

—. 2011c. "How Culture Shapes Community: Bible Belief, Theological Unity, and a Sense of Belonging in Religious Congregations." The Sociological Quarterly, to appear.

Warner, R. Stephen. 1994. "The Place of Congregation in the Contemporary American Religious Configuration." American Congregations: New Perspectives in the Study of Congregations, 54-100. Chicago: University of Chicago Press.

Welch, Kevin W. 1981. "An Interpersonal Influence Model of Traditional Religious Commitment." The Sociological Quarterly 22, no. 1:81-92.

Wellman, Barry, and S. D. Berkowitz. 1988. "Introduction: Studying Social Structures." Social Structures: A Network Approach, 1-18. Cambridge: Cambridge University Press.

White, Richard H. 1968. "Toward a Theory of Religious Influence." The Pacific Sociological Review 11, no. 1:23-28.

Whitehead, Andrew L. 2010. "Sacred Rites and Civil Rights: Religion's Effect on Attitudes Toward Same-Sex Unions and the Perceived Cause of Homosexuality." Social Science Quarterly 91, no. 1:63-79.

- forthcoming. "Gender Ideology and Religion: Does a Masculine Image of God Matter?" Review of Religious Research.

Wuthnow, Robert. 2011. "Intimate Knowledge as a Concept for Further Research in Studies of Religion." The ARDA Guiding Papers Series. http://www.thearda.com/rrh/ papers/guidingpapers/Wuthnow.pdf (retrieved April 29, 2011). 